YYÜ Eğitim Fakültesi Dergisi (YYU Journal of Education Faculty), 2018; 15(1):698-722, http://efdergi.yyu.edu.tr

\title{
Drama Temelli Fen Etkinliklerinin Okul Öncesi Öğrencilerinin Sosyal Beceriler Üzerine Etkisinin İncelenmesi: Besinler Konusu Örneği * Yılmaz KARA ${ }^{* *}$, Burcu ASLAN ${ }^{* * *}$
}

Öz: Bu çalışmada okul öncesi dönem eğitimi planı, öz bakım becerileri gelişim alanında yer alan doğru ve dengeli beslenme kazanımları dikkate alınarak hazırlanan drama temelli fen eğitimi etkinliklerinin mevcut yönteme oranla sosyal beceriler üzerine etkisini belirlemek amaçlanmıştır. Araştırmada yarı deneysel araştırma yöntemi benimsenmiştir. Çalışma, 20172018 eğitim öğretim yılında bir devlet okulunda eğitim görmekte olan beş yaş grubu öğrencileri ile yürütülmüştür. Çalışma toplam 37 öğrenci ile yürütülmüştür. Rastgele atama yöntemi ile okulda mevcut sınıfların biri deney, diğeri karşılaştırma grubu olarak tayin edilmiştir. Deney grubunda 18 karşılaştırma grubunda ise 19 öğrenci yer almıştır. Deney grubundaki öğrencilere besinler konusu drama temelli öğretim ile öğretilmiştir. Karşılaştırma grubunda ise besinler konusu aynı araştırmacı tarafından mevcut yöntem ile öğretilmiştir. Erken çocukluk döneminde bazı sosyal becerilerin ölçülmesi için Sosyal Becerileri Değerlendirme Ölçeği verilerin toplanmasında işe koşulmuştur. Deney ve karşılaştırma gruplarında gerçekleştirilen uygulamadan iki hafta önce ve iki hafta sonra okul öncesi dönem öğrencileri okul ortamında ölçek üzerinden gözlemlenmiştir. Gözlem sonuçlarından elde edilen veriler puanlara dönüştürülerek bilgisayar ortamına aktarılmış ve istatistik programı aracılığı ile analiz edilmiştir. Analiz sonuçları besinler konusunun öğretiminde drama yöntemi kullanılmasının öğrencilerin bazı sosyal becerilerini (kişiler arası beceriler, kendini kontrol etme, sözel

* Bu çalışma ikinci yazarın "yaratıcı drama uygulamalarının okul öncesi dönemi öğrencilerinin besinler konusundaki öğrenmelerine ve sosyal uyum becerileri kazanmalarına etkisi” adlı yüksek lisans tez çalışmasının bir bölümünden üretilmiştir.

** Dr. Öğr. Üyesi Bartın Üniversitesi, Eğitim Fakültesi, Matematik ve Fen Eğitimi Bölümü/E-mail: yilmazkaankara@gmail.com. Orcid No: 0000-0001-6897-3245.

*** Öğrenci Bartın Üniversitesi, Eğitim Bilimleri Enstitüsü, Matematik ve Fen Eğitimi A.B.D./E-mail: burcuaslann34@gmail.com. Orcid: 0000-0002-0517-5294.

Gönderim: 17.04.2018 Kabul:15.07.2018 Yayın:10.09.2018


YYÜ Eğitim Fakültesi Dergisi (YYU Journal of Education Faculty), 2018; 15(1):698-722, http://efdergi.yyu.edu.tr

açıklama ve dinleme becerileri) artırdığını ortaya çıkarmıştır. Okul öncesi dönem fen eğitiminde drama temelli öğretime yer verilmesi teşvik edilmeli ve öğretmenlerin drama temelli etkinlik tasarlama, uygulama ve değerlendirme becerileri edinmeleri sağlanmalıdır.

Anahtar Kelimeler: Fen eğitimi, Drama, Sosyal beceriler, Okul öncesi.

\section{A Research on Determining the Effect of Drama Based Science Activities on Social Skills in the Teaching of Nutrients Issue}

Abstract: The purpose of the study was determining the effect of drama-based science activities on social skills against to ongoing teaching method considering the correct and balanced nutrition objectives in progress field of self-care skills in the pre-school education plan. The quasi-experimental research method had been adopted to accomplish this purpose. The study group was included of five-year-old students who are studying at a public school in the 2017-2018 academic year. One of the existing classes in the school was designated as the experimental group while the other assigned as the comparison group with the random assignment method. The nutrition issue was taught with drama-based teaching to the children in the experimental group. In the comparison group, the subject of nutrition was instructed by the same researcher as usual. The social skills assessment scale was used as a data collection tool to measure some social skills in early childhood. Two weeks before and after the application, preschool students were observed on a scale in the school setting. The data obtained from the observation results were converted into points and transferred to the computer environment and analyzed utilizing a statistical program. The results of the analysis revealed that using the drama method in the teaching of the nutrients topic increased students' social skills (interpersonal skills, self-control, verbal explanation and listening skills). The use of drama-based teaching in pre-school science education should be encouraged and teachers should be given the ability to design, implement and evaluate drama-based activities. 
YYÜ Eğitim Fakültesi Dergisi (YYU Journal of Education Faculty), 2018; 15(1):698-722, http://efdergi.yyu.edu.tr

Keywords: Science education, Drama, Social skills, Pre-school.

\section{Giriş}

Sosyal bir etmen olarak insanın toplumda kendini ifade etmesi ve toplumsal ilişkiler geliştirmesi önemli becerilere sahip olmasını gerektirmektedir. Bireyin yaşadığı toplumun sosyal yaşantısına uygun davranabilmesi olarak tanımlanan sosyal beceriler insanlar arasında iletişim kurulmasında ve toplumsal hedeflerin başarılmasında oldukça önemlidir (TapiaGutierrez \& Cubo-Delgado, 2015). Sosyal beceriler, başkaları tarafindan olumlu ve olumsuz pekiştireçlerle ortaya çıkarılan, cezalandırma ya da söndürerek ortaya çıkması engellenebilen karmaşık beceriler olarak tanımlanmaktadır (Demir, Jaafar, Bilyk ve Ariff, 2012). Sosyal beceri tanımlarının ortak noktası sosyal ortamda kişilerle iletişimin olumlu olmasını sağlayan ve bir sosyal ortamda yapılması beklenen davranışlar bütünü olarak ifade edilmektedir. O halde sosyal beceriler öncelikle çocuklara kazandırılmalı ve yaşla birlikte gelişen sosyal çevreye uygun olarak sosyal becerilerin gelişimi teşvik edilmelidir (Venter, 2010).

Beceri kazanmada okul öncesi eğitime büyük önem verilmektedir. Okul öncesi eğitimde bedensel, zihinsel, sosyal, duygusal, dil becerileri kazandırılır. Okul öncesi eğitim, bireyin ailesinden ilk kez ayrıldığı, akranlarıyla sosyal bir ortamı paylaşmaya başladığı süreç olarak görülmektedir (Schiller, 2008). Sosyal bir ortam olarak okul öncesi eğitim sosyal beceriler kazanma ve yaşama hazırlık yapmada önemli görevler üstlenmektedir. $\mathrm{Bu}$ beceriler kazandırılmaya çalışılırken bireyin gelişim dönemi ve bireysel özelliklerine dikkat edilmeli, birey iyi tanınmalıdır (Sazak, 2013). Bireyi tanımadan yapılan eğitim, öğretim ve beceri gelişimini sürecini olumsuz etkilemenin yanı sıra birey üzerinde doğrudan olumsuz etkiler meydana getirmektedir. Birey bu dönemde uygun bir eğitimle desteklenmezse bazı gelişim alanlarında ve becerilerde yetersizlikler görülebilir (Uysal ve Kaya Balkan, 2015). 
YYÜ Eğitim Fakültesi Dergisi (YYU Journal of Education Faculty), 2018; 15(1):698-722, http://efdergi.yyu.edu.tr

Beceri eğitimi yapılırken cinsiyet, yaş, gelişim dönemi, bireysel özellikler, sosyokültürel çevre gibi özelliklere dikkat edilmesi gerekmektedir (O'Neill, 2014). Bireyin sahip olduğu özellikler doğrultusunda beceri eğitimi sürecinde benimsenecek öğretim yöntemi belirlenmelidir (Johns, Crowley \& Guetzloe, 2005). Beceri eğitiminde bireyi aktif kılan, yaparak yaşayarak öğrenmesine olanak sağlayan, yaratıcı fikirlerin ortaya çıkmasına zemin oluşturan, diğer bireylerle olumlu sosyal ilişki kurmayı sağlayan öğretim yöntemleri öne çıkmaktadır. Beceri eğitiminde işe koşulabilecek öğretim yöntemlerinden biri de drama temelli öğretim olarak görülmektedir (Szecsi, 2008).

Drama temelli öğretimde birey öğrenme sürecinin bir parçası olarak kabul edilmekte ve sürecine aktif olarak katılması sağlanmaktadır (Abac1, Tepeli ve Erbay, 2015; Stavrou, 2010). Yaratıcı drama yöntemiyle gerçekleştirilen öğrenme sürecinde birey gözlemde bulunmakta ve analizler yapmaktadır (Soydan ve Quadir, 2013). Yaptığı bu analizler sonucunda öğrendiği bilgi ve beceriyi anlamlaştırarak kalıcı hale getirmektedir. Bu nedenle drama temelli öğretim ezberci ve dayatmacı eğitim anlayışına karşı güçlü bir alternatif olarak kabul edilmektedir (Çetingöz \& Günhan, 2012; Pehlivan ve Gökbulut, 2015).

Toplumun asıl unsuru olan birey yaşantısı boyunca sayısız sorunla karşılaşmakta ve bu sorunlarla başa çıkmak için çeşitli beceriler geliştirmek durumunda kalmaktadır. Hem bireysel hem de sosyal sorunların çözüme ulaşmasında drama temelli öğrenme önemli firsatlar sunmaktadır (Freeman, Sullivan \& Fulton, 2003). Drama temelli öğrenme bireye yaşanması olası ya da yaşanmış bir durum içinde yer alma olanağı vermektedir. Böylece birey içinde yer aldığı kontrollü bir ortamda hedef alınan durumla ilgili deneyimler kazanma şansını yakalamaktadır. Kazanılan deneyim günlük yaşamda karşılaşılan problemlerin çözümüne zemin oluşturmaktadır. Birey tüm bunları yaparken grupta yer alan diğer bireylerin düşüncelerini öğrenmekte ve sosyal becerilerini geliştirmektedir (Çakır, 2017). 
YYÜ Eğitim Fakültesi Dergisi (YYU Journal of Education Faculty), 2018; 15(1):698-722, http://efdergi.yyu.edu.tr

Okul öncesi dönemde drama temelli eğitim birden fazla gelişim alanında ilerleme göstermesine zemin oluşturmaktadır (Bulut Özek, 2016). Dil ve iletişim alanında yapılan çalışmalar drama temelli öğretimin alıcı ve ifade edici dil gelişimi, zihinsel sözlükteki kelime sayısı artışı, uzun cümle kurabilme, verilen yönergeleri anlayarak anlatma ve iletişim becerisi geliştirmede etkili olduğunu ortaya koymaktadır (Demir ve Kılınç, 2018; Hornáčková, 2016; Hui, Cheung, Wong \& He, 2011; Mourettou, 2000). Okul öncesi eğitimde serbest zaman, sanat, oyun, müzik, dil ve fen derslerinde bazı sosyal beceriler kazandırılmaktadır (Çetingöz ve Günhan, 2010).

Okul öncesi eğitimde öğrenmeye ek olarak becerileri destekleyen derslerden biri fen eğitimidir (Abed, 2016; Precious, \& McGregor, 2014). Okul öncesi fen ve doğa etkinlikleri kapsamında grup çalışmalarına yer verilmesi öğrenciler arasında iletişimi artırmakta ve işbirliği sağlamaktadır. Akranlarıyla faaliyetler göstererek sorunlara çözüm bulma çalışmaları çocukların sosyal yönlerini geliştirmektedir (Bencze \& Upton, 2006). Bu nedenle okul öncesi dönem öğretmenleri, derslerinde konu alan bilgisinin yanı sıra sosyal becerileri geliştirmeye yönelik pedagojik bilgilerini de işe koşmak durumundadır (Arieli, 2007; Bakırcı, Çepni ve Ayvac1, 2015).

Alan yazın incelendiğinde drama temelli öğretim uygulamalarının sosyal becerileri kazanmada etkili olduğunu ortaya koyan çalışmalara rastlanmaktadır (Avcıoğlu, 2012; Kaf, 2000; Kara ve Çam, 2007; Namdar ve Çamadan, 2016; Naycı ve Adıüzel, 2017; Yılmaz, 2013). Bu çalışmalar arasında okul öncesi dönem öğrencilerinin sosyal beceriler edinmesinde drama uygulamalarının olumlu katkılar ortaya çıkardığına vurgu yapan çalışmalar da bulunmaktadır (Neslitürk, 2013; Soydan \& Quadir, 2013; Ökten ve Gökbulut, 2015; ; Özbey, 2012; Uysal ve Kaya Balkan, 2015). Ancak, okul öncesi dönemde drama temelli fen etkinliklerinin sosyal beceri öğretimine etkisini konu edinen sınırlı sayıda çalışmaya rastlanmıştır (Herreid, 1999; Pongsophon, Yutakom, \& Boujaoude, 2010). Bu nedenle, bu 
YYÜ Eğitim Fakültesi Dergisi (YYU Journal of Education Faculty), 2018; 15(1):698-722, http://efdergi.yyu.edu.tr

çalışmanın amacı okul öncesi dönem eğitimi planı öz bakım becerileri gelişim alanında yer alan doğru ve dengeli beslenme kazanımları dikkate alınarak hazırlanan drama temelli fen eğitimi etkinliklerinin genelde sosyal beceriler, özelde kişiler arası beceriler, kendini ifade edebilme becerileri, sözel beceriler ve dinleme becerileri üzerine etkisini incelemek olarak belirlenmiştir.

\section{Yöntem}

\section{Araştırma Modeli}

$\mathrm{Bu}$ araştırmada, yaratıcı drama uygulamalarının okul öncesi dönemi öğrencilerinin sosyal uyum becerilerine etkisini mevcut yöntemin etkisine oranla karşılaştırmak amacıyla yarı deneysel araştırma yöntemi benimsenmiştir. Yarı deneysel araştırma modeli, deneysel yöntemin tam olarak uygulanamadığı eğitim araştırmalarında uygulamaların yapılacağı gruplara seçkisiz yöntemle atamaların yapıldığı araştırma deseni olarak adlandırılmaktadır (Çepni, 2007). Denekler deneysel işlem öncesinde ve sonrasında bağımlı değişkenle ilgili olarak ölçüldükleri için ilişkili desen, farklı deneklerden oluşan deney ve kontrol gruplarının ölçümleri karşılaştırıldığı için ilişkisiz desendir (Karasar, 2016).

\section{Çalışma Grubu}

Çalışma, 2017-2018 eğitim öğretim yılında bir devlet okulunun ana sınıfında eğitim görmekte olan beş yaş grubu öğrencilerinin katılımı ile yürütülmüştür. Rastgele atama yöntemi ile okulda mevcut sınıflardan biri deney grubu, diğeri karşılaştırma grubu olarak atanmıştır. Deney grubu 10’u kız, 8'i erkek toplam 18 öğrenci, karşılaştırma grubu ise 7'si kız, 12'si erkek toplam 19 öğrenciden oluşmuştur. Araştırmaya katılan toplam 37 öğrenci katılmıştır. Bu öğrencilerin 17'si (\%45.9) k1z, 20’si (\%54.1) erkektir. 
YYÜ Eğitim Fakültesi Dergisi (YYU Journal of Education Faculty), 2018; 15(1):698-722, http://efdergi.yyu.edu.tr

\section{Veri Toplama Aracı}

Erken çocukluk döneminde bazı sosyal becerilerin ölçülmesi için Sosyal Becerileri Değerlendirme Ölçeği (4-6 Yaş) ölçeğine yer verilmiştir. Avcıŏlu (2007) tarafından geliştirilen ölçekte, 4-6 yaş okul öncesi dönemi öğrencilerinin sahip olması gereken sosyal becerilere ilişkin maddelere yer verilmiştir. Sosyal beceri maddeleri 4 alt ölçekte toplanmıştır. Bu alt ölçekler; Kişiler Arası Beceriler (KB), Kendini Kontrol Etme Becerileri (KKEB), Sözel Açıklama Becerileri (SAB), Dinleme Becerileri (DB) olup toplam 35 maddeden meydana gelmiştir. Ölçülmesi hedeflenen sosyal becerilerine göre hazırlanan ölçek maddeleri olumlu ifadeler içermektedir. Sosyal becerileri değerlendirme ölçeği beş dereceden oluşan likert tipi ölçektir. Bu ölçekte düşük puana sahip olan okul öncesi öğrencisinin istenilen düzeyde sosyal becerilere sahip olmadığı, yüksek puana sahip olan okul öncesi dönemi öğrencisinin istenilen düzeyde sosyal becerilere sahip olduğu sonucuna ulaşılmaktadır. Sosyal Becerileri Değerlendirme Ölçeği için Avcıŏglu (2007) tarafından hesaplanan cronbach alpha güvenirlik katsayısı 0.98 iken çalışmamızda elde edilen veriler üzerinden aynı yöntemle hesaplanan güvenirlik katsayısı 0.89 olmuştur. Avcıoğlu (2007) tarafından yürütülen faktör analizi sonuçları ölçekte yer alan maddelerin faktör yükü değerlerinin 0.40 ile 0.86 arasında değiştiğini göstermiştir. Sonuç olarak, yapılan geçerlik ve güvenirlik analizi sonuçları ölçeğin çalışmada kullanılabilecek geçerlik ve güvenirliğe sahip olduğunu ortaya koymaktadır (Çepni, 2007).

\section{Yaratıcı Drama Etkinliklerinin Hazırlanması}

Araştırma amaçları doğrultusunda yapılacak ve eğitim uygulamalarında işe koşulacak drama etkinliklerinin hazırlanması amacıyla ilk olarak alan yazın taraması yapılmıştır. Etkinliklerin konu ve kapsamının belirlenmesinde Millî Eğitim Bakanlığı (MEB) tarafından hazırlanan Okul Öncesi Eğitim Programında yer verilen “öz bakım becerileri” gelişim alanındaki "doğru ve dengeli beslenme" ile sosyal ve duygusal gelişim alanında yer alan 
YYÜ Eğitim Fakültesi Dergisi (YYU Journal of Education Faculty), 2018; 15(1):698-722, http://efdergi.yyu.edu.tr

kazanımlar incelenmiş ve sosyal gelişim alanını destekleyen kazanımlar çalışma kapsamına alınmıştır (MEB, 2016).

Yaratıcı drama uygulamalarını içeren makaleler, tezler ve kitaplar incelenmiştir. Ayrıca Türkiye'deki yaratıcı drama uzmanlarının drama uygulamalarına dönük çalışmalar, eserler ve örnek drama senaryoları gözden geçirilmiştir (Abed, 2016; Çetingöz ve Günhan, 2010; Mjanger, 2014; Precious \& McGregor, 2014; Smith, 2006; Varelas, Pappas, Tucker-Raymond, Kane, Hankes, Ortiz \& Keblawe-Shamah, 2010). Örnek senaryoların incelenmesinin ardından araştırmada uygulanacak olan sosyal uyum becerilerini kapsayan besinler öğretimi yaratıcı drama uygulamalarının yazımına geçilmiştir.

Çalışma kapsamında hazırlanan yaratıcı drama senaryoları üç aşamadan meydana gelmektedir (Önder, 2016). Birinci aşama 1sınma aşamasıdır. Isınma aşamasında okul öncesi dönem öğrencileri, derse ve konuya oyun ve örnek olay yöntemi benimsenerek motive edilerek hazırlanmaya çalışılmıştır. İkinci aşama canlandırma aşamasıdır. Canlandırma aşamasında esnek kuralları olan bir oyun bağlamında konuya ilişkin deneyim yaşamaları sağlanmıştır. Son aşama ise açık uçlu soruların yer aldığı yansıtma/değerlendirme aşamasıdır. Değerlendirme aşamasında konuya yönelik değerlendirme çalışmalarına yer verilmiştir. Değerlendirme aşamasında, yansıtıcı sorular üzerinden katılımcıların akranlarının duygu ve düşüncelerini öğrenmelerine, gizil kalan yaratıcı fikirlerin açığa çıkması sağlanarak sosyal becerilerini güçlendirmelerine olanak sağlayacak unsurlara yer verilmiştir. Taslak yaratıcı drama etkinlikleri yazılırken uygulama esnasında kullanılacak olan çalışma yaprakları ve öğretim materyalleri de hazırlanmıştır. Böylece uygulamada kullanılacak öğretim materyalleri ile drama etkinlikleri eş zamanlı olarak geliştirilmiştir.

Bir taslak halinde hazırlanan yaratıcı drama uygulamaları altı okul öncesi öğretmeni, iki fen bilgisi ve bir biyoloji öğretmeninden oluşan uzman ekip ile paylaşılmıştır. Uzmanlardan hazırlanan yaratıcı drama etkinliklerini araştırma amaçlarına uygunluk bakımından 
YYÜ Eğitim Fakültesi Dergisi (YYU Journal of Education Faculty), 2018; 15(1):698-722, http://efdergi.yyu.edu.tr

değerlendirmeleri istenmiştir. Uzmanlar hazırlanan etkinliklerin öğrenci seviyesi ile uyumlu olduğunu ve araştırma amaçlarını yerine getirmede kullanılabileceğini ifade etmiştir. Ancak drama etkinliklerinin daha fazla oyun bağlamında hazırlanması gerektiğini, katılımcıların günlük hayatta daha sık deneyimledikleri bağlamlara yer verilmesinin yerinde olacağını ve etkinliklerin işitsel ve görsel öğretim araçları ile desteklenmesi gerektiğini ifade etmişlerdir. Bu görüşler doğrultusunda hazırlanan taslak drama etkinlikleri gözden geçirilmiş ve gerekli düzeltmeler yapılmıştır. Böylece yaratıcı drama etkinlikleri ile uygulamaya dönük öğretim materyalleri geliştirilmiş ve uygulamaya hazır hale getirilmiştir.

\section{İșlem Basamakları}

Çalışma süresince deney ve kontrol gurubunda bulunan öğrencilere okul öncesi dönem öğretim programında yer alan besinler konusu öğretilmiştir. Deney grubundaki öğrencilere besinler öğretimi yaratıcı drama yöntemiyle öğreterek farklılık kazandırmaya çalışılmıştır. Besinler öğretimi için altı hafta boyunca uygulanan yaratıcı drama uygulamaları çalışma planı tabloda gösterilmiştir.

Tablo 1 Fen etkileri dersi besinlerimiz konu başlıkları ve süresi

\begin{tabular}{ll}
\hline KONU & SÜRE \\
\hline Beden ve besin temizliği & 2 Ders Saati \\
Yararlı ve zararlı besinler & 2 Ders Saati \\
Bitkisel ve hayvansal besinler & 2 Ders Saati \\
Kış meyve ve sebzeleri & 2 Ders Saati \\
Besin grupları & 2 Ders Saati \\
Öğ̈̈n kavramı & 2 Ders Saati \\
\hline
\end{tabular}

Tablo 1'de verilen fen etkinlikleri dersi besinlerimiz konu başlıklarına uygulanan örnek yaratıcı drama uygulaması şu şekildedir:

Beden ve Besin Temizliği: Öğrencilerin dikkatini konuya çekmek için kısa bir örnek olay durumu anlatılır. İşitsel materyal (şark1) verilerek sözlere uygun hareketler yapılır. Uygulama aşamasına geçmeden önce pandomim çalışmasına yer verilerek canlandırma aşamasına zemin oluşturulur. Canlandırma aşaması için beden ve besin sağlığını içeren kısa bir reklam filmi canlandırmaları istenir. 
YYÜ Eğitim Fakültesi Dergisi (YYU Journal of Education Faculty), 2018; 15(1):698-722, http://efdergi.yyu.edu.tr

Karşılaştırma grubunda ise besinler konusu aynı araştırmacı tarafından mevcut yöntem ile öğretilmiştir. Mevcut öğretim ortamında düz anlatım yöntemi ve soru cevap tekniklerinin ağırlıkta olduğu öğretmen merkezli yöntem benimsenmiştir. Besinler konusu araştırmacı tarafından dikkat çekici sorular sorularak başlamıştır. Görsel materyal kullanılarak düz anlatım ve soru cevap teknikleri ile sürdürülmüştür.

\section{Verilerin Toplanması}

Yaratıcı drama etkinlikleri öncesi ve sonrasında çalışmada yer alan her bir öğrencinin sosyal beceri değişimlerini belirlemek için ön ölçüm ve son ölçümler yapılmıştır. Uygulamadan iki hafta önce ve uygulamadan iki hafta sonra okul öncesi dönem öğrencileri okul ortamında gözlemlenmiştir. Yapılan gözlemlerin ardından çalışmanın yapıldığı okuldaki öğretmenlerle bir araya gelinmiş ve her bir öğrenci için ortak kararlar alınarak ölçekte yer alan sosyal beceri ifadeleri işaretlenmiştir.

\section{Veri Analizi}

Çalışmada okul öncesi dönem öğrencilerinin sosyal becerileri sosyal becerileri değerlendirme ölçeği ile belirlenmiştir. Ölçek maddelerine verilen tepkilerin dereceleri "Her zaman yapar”, "Çok sık yapar”, "Genellikle yapar”, "Çok az yapar” ve "Hiçbir zaman yapmaz” biçimindedir. Bu dereceler "Her zaman yapar" 5, "Çok sık Yapar"4, "Genellikle Yapar” 3, “Çok az yapar” 2, "Hiçbir zaman yapmaz” derecesine ise 1 puan verilerek puana çevrilmiştir.

Araştırmada yer verilen sosyal beceri değerlendirme ölçeği (4-6 Yaş) ön ölçüm son ölçümden elde edilen puanlar SPSS 22 paket programına aktarılıp normal dağılım gösterip göstermediği analiz edilmiştir. Yapılan Kolmogorov-Smirnov ( $\mathrm{p}=0.200>0.05)$ ve Shapiro-Wilk $(\mathrm{p}=0.212>0.05)$ normallik analizleri sonucunda ölçekten elde edilen verilerin normal dağılım gösterdiği sonucuna ulaşılmıştır. Bu nedenle, ölçekten elde edilen sosyal beceri verilerine parametrik ölçümlerde kullanılan Bağımsız örneklem t-testi ve tek örneklem t-testi uygulanmıştır. 
YYÜ Eğitim Fakültesi Dergisi (YYU Journal of Education Faculty), 2018; 15(1):698-722, http://efdergi.yyu.edu.tr

\section{Bulgular}

Araştırma kapsamında drama yöntemi ve mevcut yöntem benimsenerek gerçekleştirilen besinler eğitimi öncesi ve sonrasında öğrencilerin sınıf ortamında sergiledikleri sosyal uyum beceri davranışları belirlenmiştir. Öğrencilerin sergilemiş oldukları davranışlar gözlemlenerek Sosyal Becerileri Değerlendirme Ölçeği her bir öğrenci için ayrı ayrı puanlanmıştır. Uygulama öncesinde, deney ve karşılaştırma gruplarında yer alan öğrencilerin almış oldukları puanların alt ölçeklere göre dağılımları karşılaştırmalı olarak Tablo 2'de sunulmuştur.

Tablo 2 Uygulama Öncesi Sosyal Beceri Puan Dă̆ılımı

\begin{tabular}{llccccc}
\hline Boyutlar & Grup & N & X & SS & t & p \\
\hline Kişiler Aras1 Beceriler & Deney & 18 & 40.056 & 4.556 & 1.112 & \multirow{2}{*}{0.274} \\
& Karş1laştırma & 19 & 38.053 & 6.222 & & \\
Kendini Kontrol Etme Becerisi & Deney & 18 & 30.000 & 5.018 & 1.363 & 0.182 \\
& Karş1laştırma & 19 & 27.158 & 7.373 & & \\
Sözel Açıklama Becerileri & Deney & 18 & 19.833 & 3.618 & -1.991 & 0.054 \\
& Karş1laştırma & 19 & 22.158 & 3.484 & & \\
Dinleme Becerileri & Deney & 18 & 16.444 & 2.854 & -1.952 & 0.059 \\
& Karş1laştırma & 19 & 18.105 & 2.307 & & \\
SBDÖ (Toplam) & Deney & 18 & 106.333 & 10.611 & 0.194 & 0.847 \\
& Karş1laştırma & 19 & 105.474 & 15.654 & & \\
\hline
\end{tabular}

Tablo 2 incelendiğinde deney ve karş1laştırma grubu öğrencilerinin uygulama öncesi puanları dikkate alındığında gruplar arasında anlamlı bir farklılık bulunmadığı anlaşılmaktadır $(\mathrm{t}=0.194, \mathrm{p}>0.001)$. Ayrıca, sosyal beceriler ölçeğinin oluşturan kişiler arası beceriler $(\mathrm{t}=1.112$, $\mathrm{p}>0.001)$, kendini kontrol etme becerisi $(\mathrm{t}=1.363, \mathrm{p}>0.001)$, sözel açıklama becerileri $(\mathrm{t}=1.991$, $\mathrm{p}>0.001)$, dinleme becerileri $(\mathrm{t}=1.952, \mathrm{p}>0.001)$ alt boyutları dikkate alındığında uygulama öncesi deney ve karşılaştırma grubunda bulunan öğrencilerinin sosyal beceri puanları arasında istatistiksel olarak anlamlı bir farklılık olmadığı ortaya çıkarılmıştır.

Besinler öğretiminin deney grubunda drama temelli fen öğretimi, karşılaştırma grubunda ise mevcut öğretim yöntemi benimsenerek öğretilmesinin ardından öğrencilerin sosyal beceriler ölçeğinden aldıkları puanlar değerlendirilmiştir. Uygulama sonrasında, deney ve karşılaştırma gruplarında yer alan öğrencilerin almış oldukları puanların alt bölümlere göre dağılımları karşılaştırmalı olarak Tablo 3'de sunulmuştur. 
YYÜ Eğitim Fakültesi Dergisi (YYU Journal of Education Faculty), 2018; 15(1):698-722, http://efdergi.yyu.edu.tr

Tablo 3 Uygulama Sonrası Sosyal Beceri Puan Dă̆ılımı

\begin{tabular}{llccccc}
\hline Boyutlar & Grup & N & X & SS & t & p \\
\hline Kişiler Arası Beceriler & Deney & 18 & 50.333 & 2.567 & 7.280 & 0.000 \\
& Karş1laştırma & 19 & 40.895 & 4.898 & & \\
Kendini Kontrol Etme Becerisi & Deney & 18 & 34.556 & 3.884 & 2.696 & 0.011 \\
& Karş1laştırma & 19 & 30.263 & 5.596 & & \\
Sözel Açıklama Becerileri & Deney & 18 & 25.444 & 2.749 & 2.353 & 0.024 \\
& Karş1laştırma & 19 & 23.263 & 2.884 & & \\
Dinleme Becerileri & Deney & 18 & 20.722 & 1.638 & 3.209 & 0.003 \\
& Karş1laştırma & 19 & 18.368 & 2.671 & & \\
SBDÖ (Toplam) & Deney & 18 & 131.056 & 7.619 & 5.352 & 0.000 \\
& Karş1laştırma & 19 & 112.789 & 12.430 & & \\
\hline
\end{tabular}

Tablo 3 incelendiğinde, öğrencilerin uygulama sonrası aldıkları puanlar dikkate alındığında deney ve karşılaştırma grubundaki öğrencilerin sosyal beceri puanları arasında deney grubu lehine anlamlı bir farklılık olduğu görülmektedir $(\mathrm{t}=5.352, \mathrm{p}<0.001)$. Bunun yanı sıra sosyal beceriler ölçeğini oluşturan kişiler arası beceriler $(\mathrm{t}=7.280, \mathrm{p}<0.001)$, kendini kontrol etme becerisi ( $\mathrm{t}=2.696, \mathrm{p}<0.05)$, sözel açıklama becerileri $(\mathrm{t}=2.353, \mathrm{p}<0.05)$, dinleme becerileri $(\mathrm{t}=3.209, \mathrm{p}<0.05)$ alt bölümleri dikkate alındığında uygulama sonrası deney ve karşılaştırma grubunda yer alan öğrencilerin puanları arasında drama ile besinler öğretimi yapılan deney grubu lehine istatistiksel olarak anlamlı bir farklılığa rastlanılmıştır.

Araştırma kapsamında gerçekleştirilen besinler öğretiminin deney ve karşılaştırma gruplarında uygulama öncesi ve sonrasında karşılaştırılmasının ardından drama yönteminin uygulandığı deney grubunda yer alan öğrencilerin uygulama öncesine göre uygulama sonrasında sosyal becerilerindeki değişim belirlenmiştir. Deney grubundaki öğrencilerin uygulama öncesine oranla uygulama sonrasında sosyal beceriler ölçeği kullanılarak puanlanan sosyal beceri davranış puanları ve alt ölçeklere göre dağılımı Tablo 4'de sunulmuştur.

Tablo 4 Deney Grubu Uygulama Öncesi ve Sonrası SBDÖ Puan Dağılımı

\begin{tabular}{lllcccc}
\hline Ölçek Boyutları & Grup & $\mathbf{N}$ & $\mathbf{X}$ & $\mathbf{S S}$ & $\mathbf{t}$ & $\mathbf{p}$ \\
\hline Kişiler Arası Beceriler & Ön-test & 18 & 40.056 & 4.556 & -8.338 & 0.000 \\
& Son-test & 18 & 50.333 & 2.567 & & \\
Kendini Kontrol Etme Becerisi & Ön-test & 18 & 30.000 & 5.018 & -3.046 & 0.004 \\
& Son-test & 18 & 34.556 & 3.884 & & \\
Sözel Açıklama Becerileri & Ön-test & 18 & 19.833 & 3.618 & -5.240 & 0.000 \\
& Son-test & 18 & 25.444 & 2.749 & -5.516 & 0.000 \\
\hline
\end{tabular}


YYÜ Eğitim Fakültesi Dergisi (YYU Journal of Education Faculty), 2018; 15(1):698-722, http://efdergi.yyu.edu.tr

\begin{tabular}{lllcccc}
\hline & Son-test & 18 & 20.722 & 1.638 & & \\
SBDÖ (Toplam) & Ön-test & 18 & 106.333 & 10.611 & -8.029 & 0.000 \\
& Son-test & 18 & 131.056 & 7.619 & -056 & \\
\hline
\end{tabular}

Tablo 4 incelendiğinde deney grubunda yer alan okul öncesi dönem öğrencilerinin uygulama öncesi ve sonrası puanları arasında anlamlı bir farklılık bulunmuştur ( $\mathrm{t}=8.029$, $\mathrm{p}<0.001)$. Ayrıca ölçeğini oluşturan kişiler arası beceriler $(\mathrm{t}=8.338, \mathrm{p}<0.001)$, kendini kontrol etme becerisi ( $\mathrm{t}=3.046, \mathrm{p}<0.05)$, sözel açıklama becerileri $(\mathrm{t}=5.240, \mathrm{p}<0.001)$, dinleme becerileri $(\mathrm{t}=5.516, \mathrm{p}<0.001)$ alt boyutları dikkate alındığında uygulama öncesi ve sonrası deney grubu öğrencilerinin puanları arasında istatistiksel olarak anlamlı bir farklılık olduğu görülmektedir.

Araştırmada son olarak mevcut öğretim yönteminin benimsendiği karş1laştırma grubunda yer alan öğrencilerin uygulama öncesine oranla uygulama sonrasında sergiledikleri sosyal becerilerindeki değişim belirlenmiştir. Karşılaştırma grubunda yer alan öğrencilerin uygulama öncesine oranla uygulama sonrasında sosyal beceriler ölçeği kullanılarak puanlanan sosyal beceri davranış puanları ve kullanılan ölçeğin alt boyutlarına göre puan dağılımı Tablo 5'de sunulmuştur.

Tablo 5 Karşılaştırma Grubu Uygulama Öncesi ve Sonrası SBDÖ Puan Dă̆ılımı

\begin{tabular}{lllcccc}
\hline Ölçek Boyutları & Grup & $\mathbf{N}$ & $\mathbf{X}$ & $\mathbf{S S}$ & $\mathbf{t}$ & $\mathbf{p}$ \\
\hline Kişiler Arası Beceriler & Ön-test & 19 & 38.053 & 6.223 & -1.564 & \multirow{2}{*}{0.126} \\
& Son-test & 19 & 40.895 & 4.898 & & \\
Kendini Kontrol Etme Becerisi & Ön-test & 19 & 27.158 & 7.373 & -1.462 & 0.152 \\
& Son-test & 19 & 30.263 & 5.596 & & \\
Sözel Açıklama Becerileri & Ön-test & 19 & 22.158 & 3.484 & -1.065 & 0.294 \\
& Son-test & 19 & 23.263 & 2.884 & & \\
Dinleme Becerileri & Ön-test & 19 & 18.105 & 2.307 & -0.325 & 0.747 \\
& Son-test & 19 & 18.368 & 2.671 & & \\
SBDÖ (Toplam) & Ön-test & 19 & 105.474 & 15.654 & -1.595 & 0.119 \\
& Son-test & 19 & 112.789 & 12.430 & & \\
\hline
\end{tabular}

Tablo 5 incelendiğinde, karşılaştırma grubunda yer alan okul öncesi dönem öğrencilerinin uygulama öncesine oranla uygulama sonrası aldıkları puanlar arasında anlamlı 
YYÜ Eğitim Fakültesi Dergisi (YYU Journal of Education Faculty), 2018; 15(1):698-722, http://efdergi.yyu.edu.tr

bir farklılık bulunmamıştır $(\mathrm{t}=1.595, \mathrm{p}>0.001)$. Ek olarak sosyal beceriler ölçeğini oluşturan kişiler arası beceriler $(\mathrm{t}=1.564, \mathrm{p}>0.001)$, kendini kontrol etme becerisi $(\mathrm{t}=1.462, \mathrm{p}>0.001)$, sözel açıklama becerileri ( $\mathrm{t}=1.065, \mathrm{p}>0.001)$, dinleme becerileri $(\mathrm{t}=0.325, \mathrm{p}>0.001)$ alt boyutları dikkate alındığında uygulama öncesi ve sonrası karşılaştırma grubu öğrencilerinin puanları arasında istatistiksel olarak anlamlı bir farklılı̆̆a rastlanılmamıştır.

\section{Tartışma, Sonuç ve Öneriler}

Aile ve yakın çevre dışında çocuğun akranları ve erişkinlerle ilk defa karşılaştığ çevre okul öncesi eğitim ortamıdır. Okul öncesi eğitim ortamında öğrenciden iletişim becerilerini ortaya çıkarması ve geliştirmesi beklenmektedir (Hornáčková, 2016; Morris, 2010). Bu durumda, okul öncesi eğitimin görevi yalnızca çocuğu ilkokul hazırlamak adına bazı temel kavramları edinmesini sağlamak değil aynı zamanda aralarında sosyal becerilerin de olduğu temel becerileri kazandırmaya başlamaktır (Çakır, 2017; Hui ve diğ., 2011). Çocuğun okul öncesi dönemde edinebileceği sosyal beceriler doğayı ve canlıları tanıma, onların işleyişi ve önemi hakkında bilgi sahibi olma, dahası kendinin farkına varma gibi temel hedefleri olan fen bilimleri derslerinde de gerçekleştirilebilir (Mjanger, 2014). Bu kapsamda çalışmamızda besinler konusunun öğretiminde drama yöntemi kullanılmasının sosyal beceriler üzerine etkisinin incelenmiş ve drama yönteminin öğrencilerin bazı sosyal becerilerini (kişiler arası beceriler, kendini kontrol etme, sözel açıklama ve dinleme becerileri) artırdığ 1 sonucuna ulaşılmıştır. Çalışmamızda elde edilen sonuç, sosyal becerileri ortaya çıkarma ve geliştirme sürecinde drama yönteminin etkili olduğunu ortaya koyan çalışmalarla örtüşmektedir (Mourettou, 2000). Mevcut öğretim yönteminin sosyal becerileri ortaya çıkarma ve geliştirmede yetersiz kaldığının altı çizilmektedir (Stavrou, 2010). Yine fen eğitiminde drama temelli çalışmaların öğrenci başarısı, tutumlarının yanı sıra beceri gelişimine katkı sağladığını ortaya koyan çalışmalarla uyum göstermektedir (Precious \& McGregor, 2014; Varelas ve diğ. 
YYÜ Eğitim Fakültesi Dergisi (YYU Journal of Education Faculty), 2018; 15(1):698-722, http://efdergi.yyu.edu.tr

al., 2010). Son olarak, okul öncesi dönemde drama ile fen eğitiminin sosyal becerileri artırmas1 okul öncesi dönem fen eğimi alanında yapılan sınırlı sayıda çalışmaya katkı sağlamaktadır.

Sosyal beceriler gerek okul öncesi dönem gerekse ilköğretimden ortaöğretim ve oradan da yüksek öğretime uzanan eğitim kademelerinde uygulanan fen bilimleri öğretim programlarında iletişim becerileri, tutum ve değerler başlı̆ğ altında öğrencilerin edinmesi gereken kazanımlar arasında yer almaktadır (Soydan \& Quadir, 2013). Fen bilimleri eğitimi öğrencilere sosyal becerilerini geliştirmede zengin olanaklar sunacak biçimde gerçekleştirilebilir. Örneğin fen kavramları öğretilirken sıklıkla benimsenen küme çalışması, performans görevleri, drama etkinlikleri, iş-birlikçi öğrenme gibi grupla öğrenme etkinlikleri öğrencilerin sosyal çevrelerini anlamlandırmalarına, iletişime geçerek kendini ifade edebilmelerine, duygularını kontrol edebilmelerine, dinleme ve sözlü ifade becerilerini geliştirebilmelerine olanak tanımaktadır (Mjanger, 2014).

Okul öncesi dönem fen bilimleri öğretiminde benimsenebilecek grupla öğrenme yöntemlerinden biri yaratıcı dramadır. Yaratıcı drama etkinlikleriyle birey, grupta yer alan arkadaşlarıyla ve çevresindeki diğer bireylerle iletişimi başlatma, sürebilme, duygu ve düşüncelerini uygun dille ifade edebilme, karşısındaki kişiyi dinleme, empati gibi vb. bazı sosyal becerileri kazanabildiği ortaya konmuştur. Drama temelli eğitimin ana hedefleri arasında kendini ifade edebilen, yaratıcı düşünebilen, özgüveni yüksek, sosyal ve merak duygusuna sahip bireyler yetiştirme yer almaktadır (Smith, 2006). Bireyin düşünce, kabul ve becerilerini öğrenme ortamına katarak deneyimler yoluyla öğrenmesi, sosyal ilişkilerini geliştirdiği ve karşısındaki bireyi anlama becerisi kazandırdığı dikkate alındığında, okul öncesi fen ve doğa etkinliklerinde drama temelli öğrenmeye yer verilmesiyle sosyal beceriler kazandırılabileceği ifade edilmektedir (Pongsophon ve di ̌̆., 2010).

Sonuç olarak, drama yöntemi kullanılarak okul öncesi dönem öğrencilerine besinler konusunun öğretilmesi öğrencilerin sosyal becerilerini artırmıştır. Sosyal becerilerin ortaya 
YYÜ Eğitim Fakültesi Dergisi (YYU Journal of Education Faculty), 2018; 15(1):698-722, http://efdergi.yyu.edu.tr

çıkması ve geliştirilmesinde besinler konusunun öğretimi içeriği oluşturan bir boyut olarak işe koşulurken drama yöntemi temelli öğrenme etkinlikleri öğrencilerin sosyalleşmelerine olanak yaratmıştır. Böylece, drama temelli fen eğitimi uygulamaları öğretim programlarında yer alan bilişsel öğrenme alanda yer alan kazanımların yanı sıra iletişim becerileri, tutum ve değerler öğrenme alanında yer alan kazanımların da edinilmesinde yararlı olmuştur (Szecsi, 2008). O halde okul öncesi dönem fen eğitiminde drama temelli öğretime yer verilmesi teşvik edilmelidir (Morris, 2010). Ayrıca öğretmenlerin drama temelli etkinlik tasarlama, uygulama ve değerlendirme becerileri edinmesi sağlanmalıdır (Mjanger, 2014; Erdemir ve Bakırcı, 2016). Drama temelli fen eğitimi etkinliklerinin farklı fen konularında, öğretim programlarının farklı öğrenme alanlarında yer alan kazanımlarının edinilmesinde ve farklı yaş, sınıf, cinsiyet gibi özelliklere sahip katılımcılar üzerine etkisi ortaya çıkarılmalıdır.

\section{Makalenin Bilimdeki Konumu}

Matematik ve Fen Bilimleri Eğitimi, Fen Bilgisi Eğitimi Anabilim Dalı

\section{Makalenin Bilimdeki Özgünlüğü}

Drama temelli öğretim uygulamalarının sosyal becerileri kazanmada etkili olduğunu ortaya koyan çalışmalar alan yazında mevcuttur. Bu çalışmalar arasında okul öncesi dönem öğrencilerinin sosyal beceriler edinmesinde drama uygulamalarının olumlu katkılar ortaya çıkardığına vurgu yapan çalışmalara da rastlanmaktadır. Ancak, okul öncesi dönemde drama temelli fen etkinliklerinin sosyal beceri öğretimine etkisini konu edinen çalışmalar sınırlı kalmıştır. Çalışmamızda okul öncesi dönem eğitimi planı dikkate alınarak hazırlanan drama temelli fen eğitimi etkinliklerinin sosyal beceriler üzerine etkisini incelemek olarak belirlenmiştir.

\section{Kaynakça}

Abacı, S., Tepeli, K. \& Erbay, F. (2015). Yaratıcı drama eğitiminin ergenlerin sosyal becerilerine etkisi. Yaratıcı Drama Dergisi, 10(2), 191-200. 
YYÜ Eğitim Fakültesi Dergisi (YYU Journal of Education Faculty), 2018; 15(1):698-722, http://efdergi.yyu.edu.tr

Abed, O.H. (2016). Drama-based science teaching and its effect on students' understanding of scientific concepts and their attitudes towards science learning. International Education Studies, 9(10), 163-173.

Arieli, B. (2007). The integration of creative drama into science teaching. Unpublished Doctoral Dissertation, Kansas State University, Kansas, US.

Avcıoğlu, H. (2007). Sosyal becerileri değerlendirme ölçeğinin (4-6 yaş) geçerlik ve güvenirlik çalışması. Abant İzet Baysal Üniversitesi Ĕ̈itim Fakültesi Dergisi, 7(2), 87-101.

Avcıŏglu, H. (2012). Zihinsel yetersizliği olan çocuklara sosyal beceri kazandırmada işbirliğine dayalı öğrenme ve drama yöntemlerinin etkililiği. Eğitim ve Bilim, 37 (163), 110-125.

Bakırcı, H., Çepni, S., Ayvacı, H. (2015). Ortak bilgi yapılandırma modeli hakkında fen bilimleri öğretmenlerinin görüşleri. Yüzüncü Yıl Üniversitesi Eğitim Fakültesi Dergisi, $12(1), 97-127$.

Bencze, L., \& Upton, L. (2006). Being your own role model for improving self-efficacy: An elementary teacher self-actualizes through drama-based science teaching. Canadian Journal of Science, Mathematics and Technology Education, 6(3), 207-226.

Bulut Özek, M. (2016). The effect of creative drama on student achievement in the course of information technologies. Journal of Education and Training Studies, 4 (6), 51-57.

Çakır, T. (2017). The opinions of preschool teacher candidates on vocational and personal achievements from the drama lesson. Journal of Human Sciences, 14(2), 2047-2060.

Çepni, S., (2007). Araştırma ve proje çalışmalarına giriş. Trabzon: Celepler Matbaacılık.

Çetingöz, D. \& Günhan, B. (2012). The effects of creative drama activities on social skills acquisition of children aged six. Çukurova University. Faculty of Education Journal, 41(2), 54-66.

Çetingöz, D. \& Günhan, B. C. (2010). Sample drama plans for preschool education. Procedia - Social and Behavioral Sciences, 2(2), 1338-1344. 
YYÜ Eğitim Fakültesi Dergisi (YYU Journal of Education Faculty), 2018; 15(1):698-722, http://efdergi.yyu.edu.tr

Demir, E. \& Kılınç, F.E. (2018). Anasınıfına devam eden çocuklara verilen drama eğitiminin çocukların zihinsel becerilerine etkisinin incelenmesi. Erken Çocukluk Çalışmaları Dergisi, 2(2), 284-308.

Demir, M., Jaafar, J., Bilyk, N. \& Ariff, M.R.M. (2012). Social skills, friendship and happiness: A cross-cultural investigation. The Journal of Social Psychology, 152(3), 379-385.

Erdemir, N. ve Bakırcı, H. (2016). Öğretmen adaylarının öğretim elemanlarından bilgi teknolojilerini kullanma konusunda beklentileri. Yüzüncü Yıl Üniversitesi Ĕ̈itim Fakültesi Dergisi, 13 (1), 275-300.

Freeman, G.D., Sullivan, K., \& Fulton, C.R. (2003). Effects of creative drama on self-concept, social skills, and problem behavior. The Journal of Educational Research, 96(3), 131138.

Herreid, C. (1999). Dialogues as case studies: A discussion on human cloning: creating drama and controversy in the science classroom. Journal of College Science Teaching, 28(4), 245-251.

Hornáčková, V. (2016). The impact of drama education on creativity development at preschool children. International Scholarly and Scientific Research \& Innovation, 10 (8), 29752979.

Hui, A.N.N., Cheung, P., Wong, S.T.K. \& He, M.W.J. (2011). How effective is a dramaenhanced curriculum doing to increase the creativity of preschool children and their teachers? The Journal of Drama and Theatre Education in Asia, 2, 21-48.

Johns, B. H., Crowley, E. P., \& Guetzloe, E. (2005). The central role of teaching social skills. Focus on Exceptional Children, 37, 1-8.

Kaf, Ö. (2000). Hayat bilgisi dersinde bazı sosyal becerilerin kazandırılmasında yaratıcı drama yönteminin etkisi. Çukurova Üniversitesi Sosyal Bilimler Enstitüsü Dergisi, 6(6), 173 184. 
YYÜ Eğitim Fakültesi Dergisi (YYU Journal of Education Faculty), 2018; 15(1):698-722, http://efdergi.yyu.edu.tr

Kara, Y. \& Çam, F. (2007). Yaratıcı drama yönteminin bazı sosyal becerilerin kazandırılmasına etkisi. Hacettepe Üniversitesi Ĕ̈itim Fakültesi Dergisi, 32, 145-155.

Karasar, N. (2016). Bilimsel araştırma yöntemi: Kavramlar ilkeler teknikler. Ankara: Nobel Akademik Yayınc1lık.

Millî Eğitim Bakanlığı (MEB) (2016). Çocuk gelişimi ve eğitimi okul öncesi ĕgitim programı. Ankara, Milli Eğitim Yayınları.

Mjanger, R. (2014). Playing with shadows-playing with words: exploring teachers' ownership through poetic inquiry in a Norwegian-Nepalese preschool teacher education project. Research in Drama Education: The Journal of Applied Theatre and Performance, 19(3), 296-312.

Morris, J.M. (2010). The imagination station: A drama education program for preschool teachers. Youth Theatre Journal, 16(1), 38-47.

Mourettou, M. (2000). The impact of drama on young children's language and social skills. Unpublished Master Dissertation, University of Warwick, Coventry, UK.

Namdar, A. O. ve Çamadan, F. (2016) Yaratıcı drama uygulamalarının öğretmen adaylarının sosyal becerilerine etkisi. Gazi Üniversitesi Gazi Eğitim Fakültesi Dergisi, 36(3): 557575 (2016)

Naycı, Ö. ve Adıgüzel, Ö. (2017). Sosyal bilgiler dersinde yaratıcı dramanın bir yöntem olarak kullanılmasının öğrenci başarısına etkisi. Eğitim ve Bilim, 42, 192, 349-365.

Neslitürk, S. (2013). Anne değerler eğitimi programının 5-6 yaş çocuklarının sosyal beceri düzeyine etkisi, Yayınlanmamış Yüksek Lisans Tezi Selçuk Üniversitesi, Konya

O'Neill, B. (2014). Using improvisational play to support social skills. Teaching Young Children, 7(3), 8-11. 
YYÜ Eğitim Fakültesi Dergisi (YYU Journal of Education Faculty), 2018; 15(1):698-722, http://efdergi.yyu.edu.tr

Ökten, K., Gökbulut, Ö. Ö. (2015). Yaratıcı Drama Yöntemiyle Okul Öncesi Çocuklarının İlişki Başlatma ve Sürdürebilme Becerilerinin Geliştirilmesi. Yaratıcı Drama Dergisi 2015, $10(2), 165-174$

Önder, A. (2016). Yaşayarak öğrenme için eğitici drama kurumsal temellerle uygulama teknikleri ve örnekleri. İstanbul: Epsilon Yayıncılık.

Özbey, S. (2012). Okul öncesi eğitim kurumuna devam eden 60-72 aylık çocuklarının sosyal beceri ve davranış problemler davranışlarının ev ve okul ortamına göre incelenmesi. Toplum ve Sosyal Hizmet, 23(2), 21-32.

Pehlivan, S. \& Gökbulut, Ö.Ö. (2015). Yaratıcı drama yöntemi ile okul öncesi dönem çocuklarına mesleklerin tanıtılması. Yaratıcı Drama Dergisi, 10(1), 39-50.

Pongsophon, P., Yutakom, N. \& Boujaoude, S.B. (2010). Promotion of Scientific Literacy on Global Warming by Process Drama. Asia-Pacific Forum on Science Learning and Teaching, 11(1), 1-38.

Precious, W. \& McGregor, D. (2014). Just imagine: Using drama to support science learning with older primary children. Primary Science, 132, 35-37.

Sazak, E.P. (2013). Özel eğitim okullarında ve sınıflarında görev yapan öğretmenlerin sosyal beceri öğretimine ilişkin bilgi düzeyleri. NWSA-Education Sciences, 9(1), 73-86.

Schiller, J. (2008). Drama for at-risk students: a strategy for improving academic and social skills among public middle school students. Unpublished Master Dissertation, Dominican University of California, San Rafael, US.

Smith, F.A. (2006). Light on trial: Using a courtroom drama to compare competing scientific hypotheses. Journal of College Science Teaching, 35(5), 16-20.

Soydan, S. \& Quadir, S.E. (2013). Observation of the effectiveness of drama method in helping to acquire the addition-subtraction skills by children at preschool phase. Educational Research and Reviews, 8(18), 1689-1697. 
YYÜ Eğitim Fakültesi Dergisi (YYU Journal of Education Faculty), 2018; 15(1):698-722, http://efdergi.yyu.edu.tr

Stavrou, C. (2010). An investigation into how drama is used to develop young people's empathy and social skills in secondary schools. Professional doctorate thesis, University of East London, London, UK.

Szecsi, T. (2008). Creative drama in preschool curriculum: Teaching strategies implemented in Hungary. Childhood Education, 85(2), 120-124.

Tapia-Gutierrez, C.P. \& Cubo-Delgado, S. (2015). Social skills for the teaching performance in Chile: Perceptions of teachers and principals. Procedia - Social and Behavioral Sciences, 197, 1069-1073.

Uysal, A. \& Kaya Balkan, İ. (2015). Sosyal beceri eğitimi alan ve almayan okul öncesi çocukların, sosyal beceri ve benlik kavramı düzeyleri açısından karşılaştırılması. Psikoloji Çalışmaları, 35-1, 27-56.

Uysal, A., Kaya Balkan, İ. (2015). Sosyal beceri eğitimi alan ve almayan okul öncesi çocukların, sosyal beceri ve benlik kavramı düzeyleri açısından karşılaştırılması psikoloji çalışmaları. Studies in Psychology, 35, 1, 27-56.

Varelas, M., Pappas, C.C., Tucker-Raymond, E., Kane, J., Hankes, J., Ortiz, I., \& KeblaweShamah, N. (2010). Drama activities as ideational resources for primary grade children in urban science classrooms. Journal of Research in Science Teaching, 47(3), 302-325.

Venter, E. (2010). Teaching social skills in the language classroom. Journal for Language Teaching, 44(2), 120-131.

Y1lmaz, S. (2013). Sosyal bilgiler derslerinde drama yöntemi ile öğretimin öğrencilerin sosyal beceri, empatik beceri ve akademik başarı düzeylerine etkisi. Yayımlanmış Doktora Tezi, Atatürk Üniversitesi, Erzurum.

Yiğit, N., Alev, N. Tural, G. \& Aydın, Ö. (2009). Exposing ways of using drama method in science teaching. Education Sciences, 4(3), 975-993. 
YYÜ Eğitim Fakültesi Dergisi (YYU Journal of Education Faculty), 2018; 15(1):698-722, http://efdergi.yyu.edu.tr http://dx.doi.org/10.23891/efdyyu.2018.84_ Araştırma Makalesi

ISSN: 1305-020 
YYÜ Eğitim Fakültesi Dergisi (YYU Journal of Education Faculty), 2018; 15(1):698-722, http://efdergi.yyu.edu.tr

\section{Summary}

Problem Statement: It is necessary for a person to develop skills as a social being. Social skills, defined as being able to behave appropriately in social life in which the individual lives and play a crucial role in the establishment of interpersonal relationships and the realization of social goals. Pre-school education as a social environment plays an important role in acquiring social skills. The developmental period should be considered in addition to individual characteristics and the individual should be well-recognized when trying to gain skills. The teaching method to be adopted in the skill training process should be determined according to the characteristics of the individual. One of the teaching methods that can be employed in skill training is seen as drama-based teaching. In drama-based instruction, the individual is considered as part of the learning process. In the same vein, the inclusion of group work within the context of pre-school science activities enhances communication among students. For this reason, pre-school teachers have to work on their pedagogical knowledge to develop social skills as well as their subject knowledge in their science lessons. In literature, studies showed that drama-based teaching practices are effective in acquiring social skills. Some of these studies emphasize the fact that pre-school students have a positive contribution to the drama practices of social skills. However, it has been found that there is a limited number of studies on the effect of drama-based science activities on social skills teaching in the pre-school period.

Purpose of the Study: The purpose of this study is to investigate the effects of drama-based science education activities, taking into consideration the correct and balanced nutrition objectives in the development field of self-care skills in preschool education plan in general, social skills especially interpersonal skills, self-expression skills, verbal skills and listening skills as well as to examine the effect on it. 
YYÜ Eğitim Fakültesi Dergisi (YYU Journal of Education Faculty), 2018; 15(1):698-722, http://efdergi.yyu.edu.tr

Method(s): The quasi-experimental research method has been adopted in the study. The study group was composed of five-year-old students who are studying at a public school in the 20172018 academic years. One of the existing classes in the school was designated as the experimental group and the other as the comparison group. The nutrition issue was taught with drama-based teaching to the students in the experimental group while the same researcher instructed the comparison group traditionally. The social skills assessment scale developed by Avcioğlu (2007) was used as a data collection tool to measure some social skills in early childhood. Preschool students were observed on a scale in the school setting two weeks before and after the application. The scores obtained from the observation results were transferred to the computer environment and analyzed using a statistical program.

Findings and Discussions: Pre-school education is the environment that children meet for the first time with the peers and adults outside the family. For this reason, pre-school students need to develop social skills including interpersonal skills, self-expression skills, verbal skills and listening skills. In this case, the task of pre-school education is not only to get the child to acquire some basic concepts to prepare primary education, but also to start to acquire basic skills, including social skills. The social skills that the child can attain in the pre-school period can also be realized in science courses, which are the primary goals of recognizing nature and living things, knowing their functioning and importance, and even becoming aware of themselves. In this context, the effect of using drama method in the teaching of nutrition subject to social skills has been examined and drama-based science activities were found to be increased some social skills of pre-school students (interpersonal skills, self-control, verbal explanation and listening skills). The result of our study overlaps with the result of the studies that reveal the effectiveness of the drama-based teaching activities in the process of developing social skills. It is underlined that the traditional teaching method is insufficient to develop social 
YYÜ Eğitim Fakültesi Dergisi (YYU Journal of Education Faculty), 2018; 15(1):698-722, http://efdergi.yyu.edu.tr

skills. The limited number of drama-based studies in science education is consistent with studies that demonstrate the contribution to skill development as well as attitudes. Finally, it is stated that social skills can be gained through drama-based science teaching activities when the emotions, thoughts and abilities of individuals are considered in pre-school.

Conclusions and Recommendations: As a result, using the drama method to teach the subjects of nutrition to preschool students increased the social skills of the students. In the emergence and development of social skills, drama-based nutrition issue activities have created opportunities for the socialization of learners. Thus, drama-based science education practices have benefited from acquisitions of communication skills, attitudes and values objectives as well as cognitive objectives in science education curricula. Therefore, the provision of dramabased teaching in pre-school science education should be encouraged. In addition, teachers should be able to acquire the ability to design, implement and evaluate drama-based activities. The impact of drama-based science education activities on different science subjects, the acquisition of educational programs in different learning areas and on participants with different characteristics such as age, class, and gender should be revealed.

Keywords: Science education, Drama, Social skills, Pre-school. 